\title{
INVESTIGATION OF TECHNOLOGY FOR OBTAINING BIOFERTILISERS BASED ON SEWAGE SLUDGE
}

\author{
Valentina Krutiakova ${ }^{1}$, Nina Pyliak ${ }^{1}$, Olena Nikipelova ${ }^{1}$, \\ Volodymyr Bulgakov ${ }^{2}$, Adolfs Rucins ${ }^{3}$, Hristo Beloev ${ }^{4}$ \\ ${ }^{1}$ Engineering and Technology Institute "Biotechnica", Ukraine; \\ ${ }^{2}$ National University of Life and Environmental Sciences of Ukraine, Ukraine; \\ ${ }^{3}$ Latvia University of Life Sciences and Technologies, Latvia; \\ 4"Angel Kanchev" University of Ruse, Bulgaria \\ adolfs.rucins@1lu.lv
}

\begin{abstract}
Substantiation of a technology for the production of biofertilisers, based on sewage sludge from the biological treatment plants with the participation of microorganisms, with phosphate-mobilising properties is an important scientific and technological problem. Agrochemical, microbiological, field, statistical studies were carried out, as a result of which there were elaborated technological stages of creating a biofertiliser, based on sewage sludge, obtained at biological treatment stations, with various fillers, with the participation of an active strain of Microbacterium barkeri LP-1. The technical parameters of this technology have been determined for the production of organic fertilisers. In the research process of the technology for the production of biofertilisers, fertilisers were obtained with the content of common forms: nitrogen - 21.7-30.7 $\mathrm{g} \cdot \mathrm{kg}^{-1}$ (at a rate of $18-20 \mathrm{~g} \cdot \mathrm{kg}^{-1}$ ); phosphorus - 14.4-33.2 $\mathrm{g} \cdot \mathrm{kg}^{-1}$ (at a rate of $10-12 \mathrm{~g} \cdot \mathrm{kg}^{-1}$ ); potassium - 5.7-11.5 g. $\mathrm{kg}^{-1}$ (at a rate of $2-5 \mathrm{~g} \cdot \mathrm{kg}^{-1}$, the efficiency of which in a field experiment in growing corn for grain ranged from $31.6 \%$ to $50.0 \%$. The developed technology makes it possible not only to utilise sewage sludge, but also to obtain biofertilisers in order to increase the soil fertility and productivity of agricultural crops.
\end{abstract}

Keywords: composts, organogenic waste, fillers, phosphate-mobilising microorganisms.

\section{Introduction}

Long-term application of chemical and organic additives significantly affects the quality and fertility of the soil, mainly by improving the availability of nutrients for plants and microorganisms. Investigations [1] have shown that the use of organic fertilisers considerably increases the microbial biomass of the soil and the activity of the soil enzymes while inorganic fertilisers have a relatively smaller effect. The use of microorganisms to improve the solubility of phosphorus in the soil can reduce dependence on chemical fertilisers in the crop production and thus increase durability [2].

The authors of [3] have studied a possibility to create microbiological preparations, based on microorganisms that mobilise phosphorus from hard-to-reach soil compounds into mobile, readily available forms. Along with the application of manure, poultry droppings, composts, straw, sawdust, forest litter, green plants, sapropel as fertilisers, the use of sewage sludge from the city sewage treatment plants as a fertiliser is of great interest. The amount of the accumulated sludge on the territory of Ukraine exceeds 5 billion tons, to which another 3 million tons of the new sewage sludge is added annually [4]. Waste from municipal services, sewage sludge in large cities and towns give rise to a lot of problems in connection with their disposal. For the majority of biological wastewater treatment plants sufficiently promising is the method of the sludge disposal as organic fertilisers [4].

In the industrially developed countries of Europe and the USA, about $30 \%$ of the urban wastewater sludge is utilised, but in Ukraine - not more than 4-5\%. There are a number of ways how to utilise sewage sludge: dumping into the seas and oceans (Great Britain discharges about 10 million tons per year), incineration (France burns almost $30 \%$ of sludge, Denmark - 100\%), burial in the soil, neutralisation and use as organic fertilisers, as an additive in the preparation of various composts, etc. [5]. The urban wastewater sludge is characterised by a high content of organic matter (up to 75\%) [5; 6]. It may be a source of phosphorus and nitrogen input into the soil; and a considerable part of potassium in the sediments is in a liquid phase of sludge and may be washed out in case of storage by $50-80 \%$. Fluctuations in the content of the main nutrients - nitrogen are 0.8-6.0\%, phosphorus - 0.6-5.6\%, potassium $-0.1-0.5 \%$ [7]. The review [8] provides information on various aspects of the use of sewage sludge, affecting the soil fertility and, further, the crop production, in order to study the possibility of using it in agronomy and horticulture.

The results of investigations of the compost, obtained from agricultural waste and sewage sludge, showed compliance with the quality criteria for use in agriculture [9]. Composting of sewage sludge is 
regarded as an important element of a waste reuse strategy. In addition, two tasks are being solved: first, one can get rid of the waste that poses threat to environmental pollution, and second, one can expand the production of organic fertilisers, the demand for which is very high. To increase the carbon content in the compost mass during composting of sewage sludge, special additives are used - fillers (crushed tree bark, sawdust, leaves, straw, peat and other organic substances) [10; 11].

Ensuring a normal level of phosphorus nutrition is one of the main conditions for the formation of high yields of agricultural crops. The soil microbiota is actively involved in the mobilisation of sparingly soluble phosphates; it has a positive effect on plants, improving their phosphorus nutrition, growth, development and productivity [12]. Therefore, the phosphate-mobilising microorganisms can become one of the components of the bioorganic fertilizers.

The purpose of the work is to study the technology for the production of compostable biofertilisers, based on sewage sludge from the biological treatment plants in the south of Ukraine, and to determine the dynamics of the development of microorganisms with phosphate-mobilising properties.

\section{Materials and methods}

The objects of the research are composts, based on sewage sludge with organic fillers of two biological treatment stations 1 and 2 in the south of Ukraine, with the participation of microorganisms, with phosphate-mobilising properties. The technology for obtaining biofertilisers provided for composting sewage sludge after three years of storage on the sludge sites with vegetable fillers -winter wheat straw and sunflower seed husks. For composting, sewage sludge was used after three years of storage on the sludge pads. According to the results of complex studies of sewage sludge from the biological treatment plants in the south of Ukraine, it is characterised by a number of positive agrochemical indicators, satisfactory sanitary and microbiological indicators, the absence of phytotoxicity in relation to higher plants; according to microbiological characteristics - these substrates are suitable for the growth and development of microorganisms of various specific actions and can be used to create composts (biofertilisers) on their basis for agriculture [13; 14]. Agrochemical indicators of sewage sludge: the mass fraction of the organic matter from the biological treatment plant 1 is $11.58 \%$ per dry matter, from the biological treatment plant $2-12.52 \%$ (standard $-40 \%$ ). The mass fraction of nutrients (\% per dry matter) at the biological treatment plant 1 : total nitrogen -6.2 (standard -1.5 ); total phosphorus -2.0 (standard -0.7 ); total potassium -0.22 (standard -0.1 ); calcium -5.20 ; magnesium - 0.80; sodium - 0.10; ash - 57.16. In sewage sludge the ratio of nutrients (units of nitrogen to phosphorus and potassium) is 1: 0.3: 0.03 , which indicates an imbalance in the content of phosphorus and potassium. In the wastewater sludge the ratio of $\mathrm{C}: \mathrm{N}$ is $1.5: 1$, and the neutral reaction of the medium (aqueous $\mathrm{pH}$ ) is 6.5 (standard is 6.5-7.5).

The mass fraction of the organic matter in the wastewater sludge from the biological treatment plants 2 is $12.52 \%$ per dry matter. The mass fraction of the nutrients (\% per dry matter): total nitrogen -5.3 ; total phosphorus -1.40 ; total potassium -0.63 ; calcium -7.6 ; magnesium -0.2 ; sodium -0.23 ; ash -54.05 . In OSV SBO 2 the ratio of nutrients is 1: 0.3: 0.11, indicating imbalance in the content of phosphorus and potassium. The $\mathrm{C}: \mathrm{N}$ ratio is 2.2 : 1 ; the neutral reaction of the medium (pH aqueous) 6.5. According to the results of the research, the content of the agrochemically valuable indicators in sewage sludge - the general and mobile forms of nitrogen - exceeds the usual indicators. The concentration of the most important chemical elements (copper, manganese, cobalt, cadmium, nickel, lead, strontium, chromium, zinc, mercury) is much lower than their maximum permitted concentrations. No mercury was found in sewage sludge from both biological treatment plants. The highest indicators of the content of the acid-soluble form of chemical elements in the wastewater sludge of both biological treatment plants vary within (\% of their gross content): for cobalt $-60-70$, nickel $-85-88$, lead - 82-97, copper - 87- 97 and zinc - 94-96; the exchangeable form (\% of their gross content), respectively, for cadmium - 20-29, manganese - 25-32 and zinc - 31-45. The sewage sludge samples contain trace concentrations of individual pesticides (hexochlorocyclohexane (lindane), heptochlor, dichlorodiphenyltrichloromethylmethane, karbofos, chlorophos, prometrine), which do not exceed the maximum permitted concentration.

The comparison of the obtained results with the normative indicators of the relevant documents that regulate the use of sewage sludge in the doses, the frequency and the scope of application in terms of the content of toxicants, indicate that sewage sludge belongs to the third classification group. This 
provides for that this sewage sludge can be used as a fertiliser in the fields at a dose of 5-6 tha ${ }^{-1}$ per dry matter once every 5-7 years with mandatory control of the background content of elements in the soil.

The agrochemical, ecological-toxicological, sanitary-bacteriological, microbiological indicators of sewage sludge were studied in certified laboratories. The moisture content of the substrate was monitored by regular measuring, using a soil moisture meter. The moisture content was determined from the first day after the compost was laid - once a week, for 8 weeks. The temperature control - in the same period, starting from the third day -2 times a week. The moisture content in the fertiliser samples was determined by the classical gravimetric method, which consists in drying the sample in a thermostat at $105^{\circ} \mathrm{C}$ to a constant value of the substrate. The phosphate-mobilising bacteria were grown in the corn molasses nutrient medium (molasses $-2 \%$, corn extract $-2 \%$, water $-96 \%, \mathrm{pH}-7.0$ ). The efficiency of using the new biofertilisers in agriculture was determined according to the existing contemporary methods [15-17]. To determine the reliability of the experiments, the research results were processed by the methods of mathematical statistics (18-19).

\section{Results and discussion}

According to the results of sanitary and hygienic investigations, no helminths, pathogenic microorganisms, including salmonella, were found in the sewage sludge of both SBOs. The titer indices

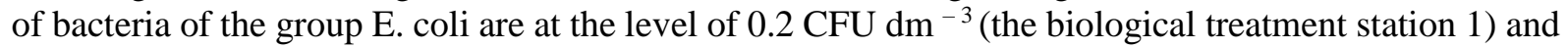
3.9 $103 \mathrm{CFU} \mathrm{dm}$ (the biological treatment station 2) with an allowable rate of $5.0103 \mathrm{CFU} \cdot \mathrm{dm}^{-3}$. Consequently, according to the sanitary-bacteriological and microbiological indicators, the samples of sewage sludge from the biological treatment plants 1 are characterised as "clean", but the samples of sewage sludge from the biological treatment plants 2 are close to the status of "the contaminated", which requires composting them when used for fertilisation. There were traces of technogenic radioactivity found in the sewage sludge samples; however, the parameters of radiological indicators ${ }^{137} \mathrm{Cs}-$ $1.50 \pm 0.03 \mathrm{~Bq} \cdot \mathrm{kg}^{-1}$ ) do not exceed the values of the background radioactivity of the soil (southern chernozem $-2.20 \pm 0.03 \mathrm{~Bq} \cdot \mathrm{kg}^{-1}$ ) in the area where these fertilisers are used, which meets the requirements of the regulatory documents. In the examined samples of sewage sludge and on controls (soil - an analogue of sewage sludge, sand - a neutral medium), the average germination percentage of the corn seeds was $95-100 \%$. Thus, practically no phytotoxic activity was revealed in the sewage sludge samples, which is because of the insignificant presence of toxicants and phytotoxic metabolites of the microbial origin in them. The compost preparation is carried out on small sites with a hard surface. The composting technology and the bioorganic fertiliser production provides for three main stages:

- preliminary composting of the substrate;

- introduction of bacteria;

- subsequent composting of the substrate.

The production technology of biofertilisers provides for composting of sewage sludge with vegetable fillers (option 1 - winter wheat straw, option 2 - sunflower seed husk) with the participation of the phosphate-mobilising bacterium Microbacterium barkeri LP-1, which was isolated from the sewage sludge of the biological treatment plants 1 and 2 in the south of Ukraine.

Preliminary composting: after three years of storage on the sludge sites the wastewater sludge with vegetable fillers, with an established optimal $\mathrm{C}$ : $\mathrm{N}$ ratio $(25: 1)$ for the mineralisation processes in a ratio 1:1 is laid in layers. The bottom and top layers are vegetable fillers.

The obtained substrate is aged for two months to carry out preliminary fermentation. The initial stage of composting is unfavourable for the development of the introduced bacterial strain. This is due to the following reasons: inhibition of the development of the introduced bacterial strain with ammonia, which is formed during the intensive decomposition of the nitrogen compounds; decreased supply of the introduced aerobic microorganisms with oxygen, which is due to the saturation of the substrate with carbon dioxide, released during the mineralisation of the organic substances; heating the substrate to a temperature of $60^{\circ} \mathrm{C}$ to $70^{\circ} \mathrm{C}$, which reduces the vital activity of the mesophilic microorganisms.

During the entire period of composting, the compost is mixed with certain regularity (once every two weeks). To mix the compost, a compost turner is used, which contributes to the saturation of the substrate with oxygen, the mechanical destruction of vegetable fillers, the maximum homogeneity of the substrate, thus accelerating the composting period. The moisture content of the substrate during 
preliminary fermentation is maintained at a level of $60 \%-70 \%$. In the composts, in a laboratory experiment, we studied the impact of the active phosphate-mobilising bacteria (Enterobacter nimipressuralis, Pseudomonas putida, Microbacterium barkeri LP-1), isolated from different ecological niches, upon the release of water-soluble forms of phosphorus during composting of sewage sludge with winter wheat straw (Fig. 1).

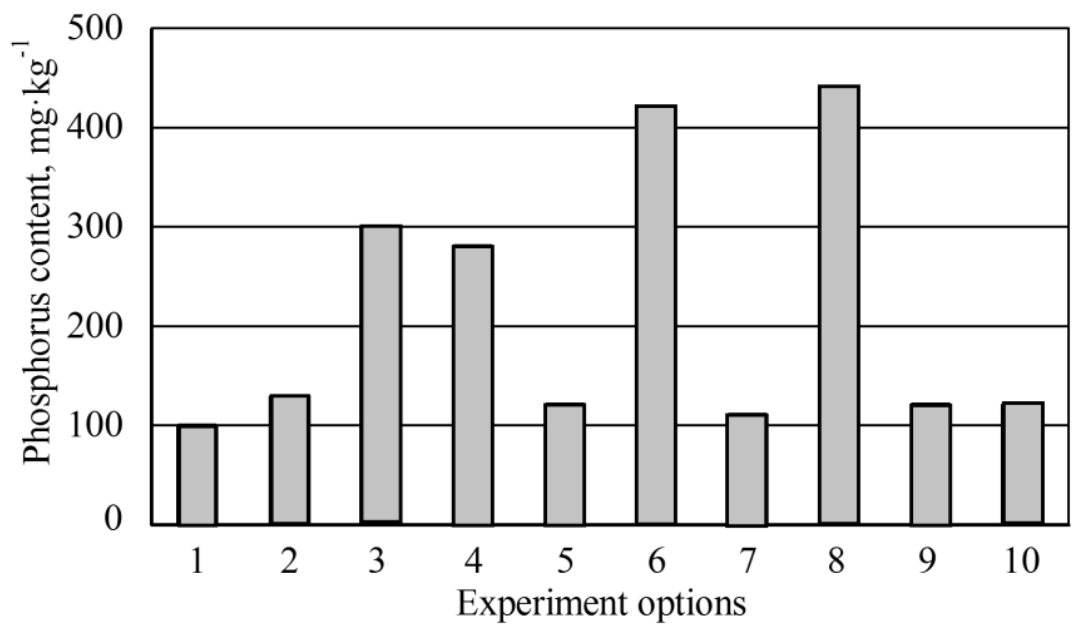

1 - Biological treatment station 1

2 - Biological treatment station 2

3 - Biological treatment station $1+$ straw

$4-$ Biological treatment station $2+$ straw

5 - Biological treatment station $1+$ straw + Enterobacter nimipressuralis

6 - Biological treatment station $1+$ straw + Microbacterium barkeri LP-1

7 - Biological treatment station $1+$ straw + Pseudomonas putida

8 - Biological treatment station $2+$ straw + Microbacterium barkeri LP-1

9 - Biological treatment station $2+$ straw + Pseudomonas putida

10 - Biological treatment station $2+$ straw + Enterobacter nimipressuralis

Fig. 1. Contents of the water-soluble forms of phosphorus in the compost, based on sewage sludge, depending on the introduced microorganism (final stage of composting)

From Fig. 1 it is evident that the largest amount of the water-soluble forms of phosphorus $\left(440 \mathrm{mg} \cdot \mathrm{kg}^{-1}\right)$ at the final stage of composting is provided by the introduction of Microbacterium barkeri $L P-1$, which can be explained by greater adaptation of this strain to the substrate, used in the experiments. The bacterial strains (Enterobacter nimipressuralis, Pseudomonas putida, the number of which is 4 times less than that of Microbacterium barkeri LP-1), isolated from other ecological niches, actively develop just in these ecological niches. Their development in sewage sludge can be limited by a number of factors. That is why Microbacterium barkeri $L P-1$ ensures greater release of the watersoluble forms of phosphorus at the final stage of composting, and it was selected for the technology of obtaining biofertilisers.

After the stage of preliminary composting $C 1$ lasting for 2 months, a suspension of the phosphatemobilising bacterium Microbacterium barkeri LP-1 is introduced (Stage C2) to the compost. The suspension of Microbacterium barkeri LP-1 is added to the substrate at the rate of $10 \%$ of the total mass of the compost with irrigation water, which ensured uniform dispersion of bacteria in the substrate. The moisture content of the substrate after the introduction of the suspension was within the range from $60 \%$ to $70 \%$. The resulting substrate is placed in piles, $1-1.5 \mathrm{~m}$ tall, $1.5-2.0 \mathrm{~m}$ wide. An increase in the size of the pile is not purposeful since this leads to self-heating of the compost, which, in turn, leads to the death of the bacteria Microbacterium barkeri LP-1. The substrate is covered with an organic material (straw), which helps stabilise the temperature. At stage C3 composting lasted for 4-5 months (depending on the season) with periodic mixing of the compost mass once every 2 weeks using a compost agitator, which contributes to the saturation of the substrate with oxygen. At all stages of the composting process the indicators of sewage sludge and fillers (K1), the humidity and temperature of the compost (K2, K3, $\mathrm{K} 4$ ) and the biofertiliser (K5) are monitored. The finished compost is a free-flowing material with a 
moisture content of 40-45\%, without unpleasant odour. Fig. 2 presents a diagram of the technological process of the WWS composting.

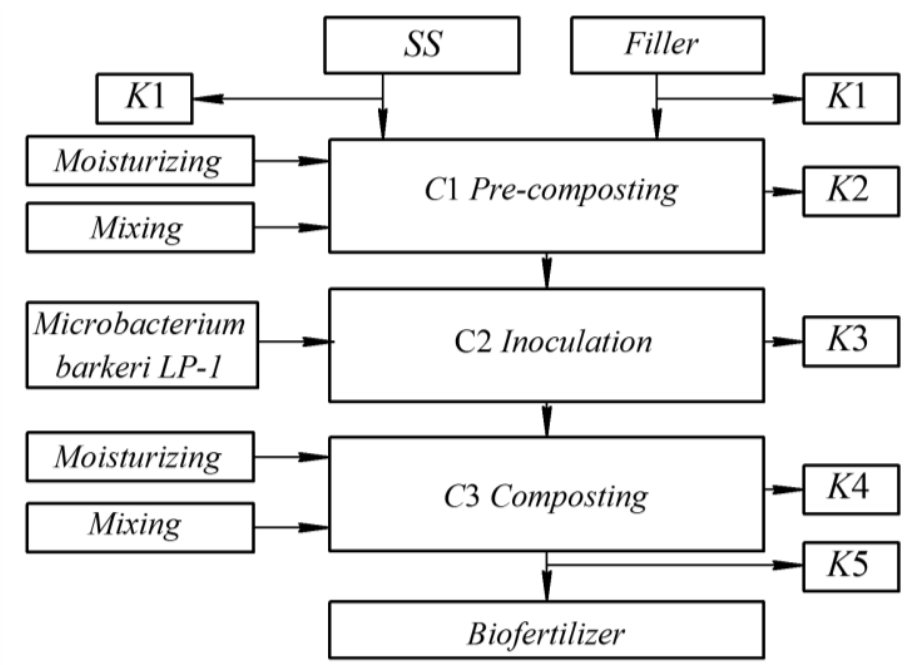

Fig. 2. Scheme of the technological process of composting sewage sludge:

$C 1-C 3$ - Stages of the technological process; $K 1-K 5$ - Control operations

Composting of sewage sludge with the participation of phosphate-mobilising microorganisms essentially affects the number of microorganisms of certain ecological-trophic groups. In the process of composting the number of microorganisms, utilising organic forms of nitrogen, increased $\left(1800.0 \pm 5.5\right.$ million $\left.\mathrm{CFU} \cdot \mathrm{g}^{-1}\right)$ (Fig. 3).

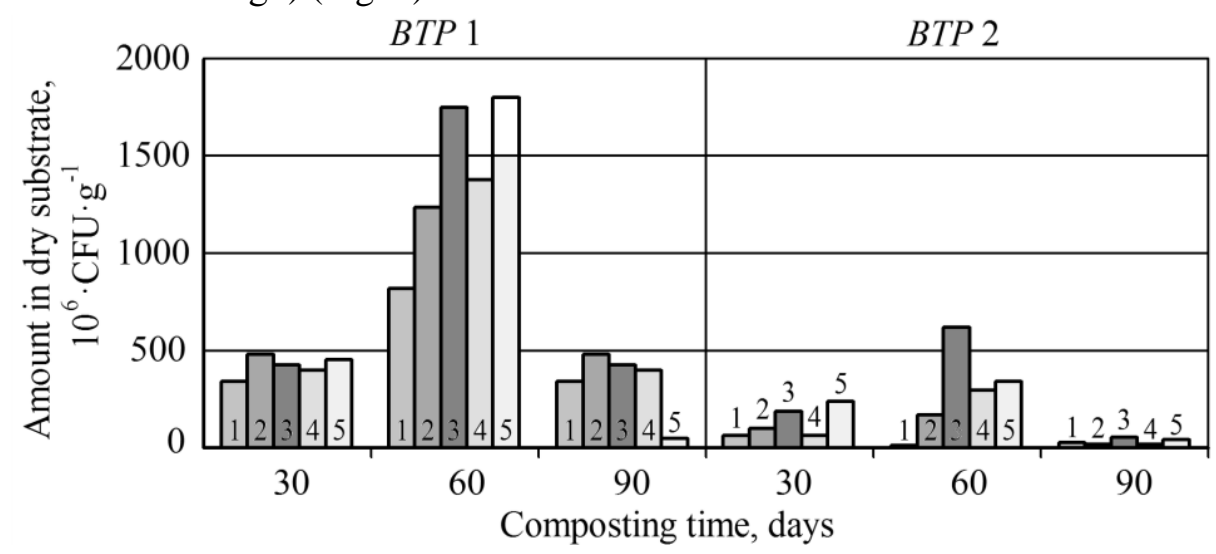

Fig. 3. Dynamics of development of microorganisms in substrates that utilise mineral forms of nitrogen: 1 - sewage sludge; 2 - sewage sludge + straw; 3 - sewage sludge + straw + strain; 4 sewage sludge + husk; 5 - sewage sludge + husk + strain

At the same time, the number of bacteria that assimilate mineral nitrogen (Fig. 4) increases more slowly $\left(3.36 \pm 6.20\right.$ million $\left.\mathrm{CFU} \cdot \mathrm{g}^{-1}\right)$, which is explained by the presence of additional organic matter in composts, based on sewage sludge with plant fillers, with the participation of phosphate-mobilising microorganisms and a small amount of mineral nitrogen compounds. There is also an increased development of representatives of other groups of microorganisms - streptomycetes and spore microorganisms - which optimise the mineral nutrition of plants $\left(116.0 \pm 1.3\right.$ million $\mathrm{CFU} \cdot \mathrm{g}^{-1}$; $826.0 \pm 6.3$ million $\mathrm{CFU} \cdot \mathrm{g}^{-1}$ respectively). Streptomycetes take part in the decomposition of plant and animal residues in the soil, as well as in the formation of humus and its mineralisation. In connection with its increased number, it can be assumed that, when using biofertilisers in agriculture, it is possible to improve the process of the humus formation in the soil. The data on the number of spore species showed that the biofertilisers, based on sewage sludge, are favourable for the development of this group of microorganisms, since they contain the necessary carbon substrates and bound nitrogen compounds. With the extension of the composting period the total number of microorganisms of all ecological and trophic groups naturally decreases. Thus, inoculation of the phosphate-mobilising microorganisms had a positive impact upon the number of individual ecological-trophic groups in composts. 


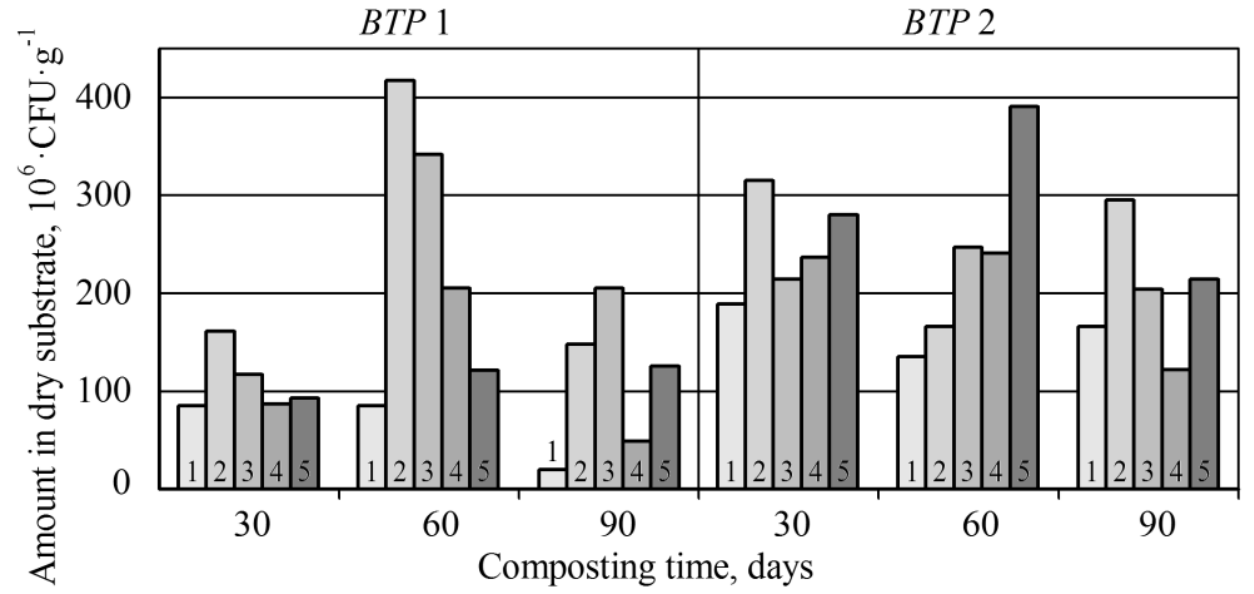

Fig. 4. Dynamics of development of microorganisms in substrates that assimilate mineral forms of nitrogen: 1 - sewage sludge; 2 - sewage sludge + straw; 3 - sewage sludge + straw + strain; 4 sewage sludge + husk; 5 - sewage sludge + husk + strain

The quality of the obtained organic fertilisers was controlled by agrochemical, ecologicaltoxicological and microbiological indicators, which confirm the reliability of the developed technology (content of common forms: nitrogen $-21.7-30.7 \mathrm{~g} \cdot \mathrm{kg}^{-1}$ (at the norm of $18-20 \mathrm{~g} \cdot \mathrm{kg}^{-1}$ ); phosphorus - 14.4$33.2 \mathrm{~g} \cdot \mathrm{kg}^{-1}$ (at the norm of $10-12 \mathrm{~g} \cdot \mathrm{kg}^{-1}$ ); potassium $-5.7-11.5 \mathrm{~g} \cdot \mathrm{kg}^{-1}$ (at the norm 2-5 g. $\mathrm{kg}^{-1}$ ). Compared to the norms, the new biofertiliser is characterised by improved agrochemical indicators. When studying the efficiency of biofertilisers, based on sewage sludge in the field experiment in the technologies for growing corn for grain, at a rate of $3 \mathrm{t} \cdot \mathrm{ha}^{-1}$ (the dry matter basis), the reserve of the nutrients increases, and the number of microorganisms that play a decisive role in the formation of the soil fertility also increases. In the experiments there was determined the impact of the developed fertilisers upon the yield of corn for grain in 2017-2019 (Table 1).

Table 1

Results of experiments on the impact of the developed fertilisers upon the yield of corn

\begin{tabular}{|c|c|c|c|c|c|}
\hline \multirow[b]{2}{*}{ Option of the experiment } & \multicolumn{5}{|c|}{ Productivity, $\mathbf{t} \cdot \mathbf{h a}^{-1}$} \\
\hline & 2017 & 2018 & 2019 & medium & $\begin{array}{l}\text { Gain to the } \\
\text { control, \% }\end{array}$ \\
\hline No fertilisers & 3.81 & 6.81 & 3.02 & 4.55 & - \\
\hline $\begin{array}{l}\text { Sewage sludge from the biological treatment plant } \\
1 \text { in a dose according to Ntot, } 100 \mathrm{~g} \cdot \mathrm{kg}^{-1}\end{array}$ & 3.90 & 8.40 & 3.49 & 5.26 & 15.6 \\
\hline $\begin{array}{l}\text { Sewage sludge from the biological treatment plant } \\
2 \text { in a dose according to Ntot, } 100 \mathrm{~g} \cdot \mathrm{kg}^{-1}\end{array}$ & 4.50 & 8.60 & 3.40 & 5.50 & 20.9 \\
\hline $\begin{array}{l}\text { Compost of sewage sludge from the biological } \\
\text { treatment plant } 1 \text { with straw at a dose of Ntot, } 100 \\
\mathrm{~g} \cdot \mathrm{kg}^{-1}+\text { strain }\end{array}$ & 5.06 & 9.10 & 3.80 & 5.99 & 31.6 \\
\hline $\begin{array}{l}\text { Sewage sludge compost from the biological } \\
\text { treatment plant } 1 \text { with husk in a dose of Ntot, } 100 \\
\mathrm{~g} \cdot \mathrm{kg}^{-1}+\text { strain }\end{array}$ & 5.03 & 9.30 & 3.82 & 6.05 & 33.0 \\
\hline $\begin{array}{l}\text { Compost of sewage sludge from the biological } \\
\text { treatment plant } 2 \text { with straw at a dose of Ntot, } 100 \\
\mathrm{~g} \cdot \mathrm{kg}^{-1}+\text { strain }\end{array}$ & 4.95 & 11.40 & 3.90 & 6.75 & 48.4 \\
\hline $\begin{array}{l}\text { Compost of sewage sludge from the biological } \\
\text { treatment plant } 2 \text { with husk in a dose of Ntot, } 100 \\
\mathrm{~g} \cdot \mathrm{kg}^{-1}+\text { strain }\end{array}$ & 4.84 & 11.80 & 3.80 & 6.81 & 50.0 \\
\hline Average & 4.58 & 9.34 & 3.60 & 5.84 & - \\
\hline$V \%$ & 11.59 & 18.64 & 8.81 & 13.90 & - \\
\hline$L C D_{05}$ & 0.64 & 2.11 & 0.38 & 0.98 & - \\
\hline
\end{tabular}




\section{Conclusions}

1. A technology for the production of bioorganic fertilisers has been studied - the technological stages of creating biofertilisers, based on sewage sludge from a biological treatment plant in southern Ukraine, with various fillers (Option 1 - winter wheat straw, Option 2 - sunflower seed husks), with the participation of an active strain of Microbacterium barkeri LP-1.

2. In the process of the research of the technology for biofertiliser production, fertilisers were obtained with the content of common forms: nitrogen - 21.7-30.7 $\mathrm{g} \cdot \mathrm{kg}^{-1}$ (at a rate of $18-20 \mathrm{~g} \cdot \mathrm{kg}^{-1}$ ); phosphorus - 14.4-33.2 g. $\mathrm{kg}^{-1}$ (at a rate of $10-12 \mathrm{~g} \cdot \mathrm{kg}^{-1}$ ); potassium - 5.7-11.5 g. $\mathrm{kg}^{-1}$ (at a rate of 2$\left.5 \mathrm{~g} \cdot \mathrm{kg}^{-1}\right)$. Compared to the norms, the new biofertiliser is characterised by higher values in terms of its agrochemical parameters.

3. According to the results of statistical processing of data for 3 years (2017-2019) of the field studies on growing corn for grain, using the new biofertilisers, the yield of corn was higher by $31.6 \%$, $33.0 \%$ (biofertiliser, based on sewage sludge from the biological treatment plant 1), and $48.4 \%$, $50.0 \%$ (biofertiliser, based on sewage sludge from the biological treatment plant 2 ) in comparison with the control.

\section{References}

[1] Ge G., Li Z., Fan F., Chu G., Hou Z., Yongchao Lian Soil biological activity and their seasonal variations in response to long-term application of organic and inorganic fertilizers. Plant Soil. 2010, 326 (1), pp. 31-44.

[2] Rathinasabapathi B., Liu X., Cao Y., Ma L.Q. Phosphate-solubilizing Pseudomonads for improving crop plant nutrition and agricultural productivity. Crop Improvement Through Microbial Biotechnology. 2018, pp. 363-372.

[3] Park J., Bolan N., Mallavarapu M., Naidu R. Enhancing the solubility of insoluble phosphorus compounds by phosphate solubilizing bacteria. 19-th World Congres of Soil Science, Brisbane, Australia. 2010, pp. 65-68.

[4] Ковалев Н.Г. Современные проблемы производства и использования органических удобрений. Вестник ВНИИМЖ (Modern problems of production and use of organic fertilizers. VNIIMZh Bulletin). Moscow, 2013, 2(10), pp. 82-101. (In Russian)

[5] Шевчук В.Я, Чеботько К.О., Разгуляев В.М. Биотехнология получения органо-минеральных удобрений из вторичного сырья (Biotechnology of obtaining organo-mineral fertilizers from secondary raw materials). Киев.: Высш. шк., 2001, 192 p. (In Ukrainian)

[6] Калетник Г.Н., Гончарук Т.В. Перспективы использования сточних канализационных вод г. Винница для подпитки полевых культур: отечественный и зарубежный опыт. Сбалансированное природопользование (Prospects for the use of wastewater sewage in Vinnitsa for feeding field crops: domestic and foreign experience. Balanced nature management). 2016; Vol.3, pp. 42-47. (In Ukrainian)

[7] Пахненко Е.П. Осадки сточных вод и другие нетрадиционные органические удобрения (Sewage sludge and other unconventional organic fertilizers). Moscow, 2007; 311 p. (In Russian)

[8] Sharma B., Sarkar A., Singh P., Singh R.P.. Agricultural utilization of biosolids: A review on potential effects on soil and plant grown. Waste Manag. 2017 Jun; 64, pp. 117-132.

[9] Alvarenga P., Mourinha C., Farto M., Santos T., Palma P., Sengo J., Morais M.-C., Cunha-Queda C. Sewage sludge, compost and other representative organic wastes as agricultural soil amendments: Benefits versus limiting factors. 2015, 40, pp. 44-52.

[10] Wang I.Y., Stavnikova O., Tay S.T., Ivanov V., Tay I.H. Biotechnology of intensive aerobic conversion of sewage sludge and food waste into fertilizer. Water Sci. Technol. 2004, 38(10), pp. 147-154.

[11] Lynch J.P., Brown K.M. Root strategies for phosphorus acquisition. The Ecophysiology of PlantPhosphorus Interactions. 2008, pp. 83-116.

[12] Волкогон В.В., Надкерничная О.В., Токмакова Л.М. Экспериментальная почвенная микробиология. Киев, 2010, 464 p. (In Ukrainian)

[13] Дышлюк В.Е., Пиляк Н.В., Лобан Л.Л. Агроэкологическая характеристика и оценка пригодности осадков сточных вод очистных сооружений г. Одесса на удобрение. Сельскохозяйственная микробиология (Agroecological characteristics and assessment of the 
suitability of sewage sludge from treatment facilities in Odessa for fertilization. Agricultural Microbiology). 2017, 26, pp. 55-62.

[14] Krutyakova V., Pilyak N., Dishliuk V., Nikipelova O. Effect of Microbacterium barkeri on the release of watersoluble forms of phosphorus in compost based on sewerage sediment. Proceedings of International Scientific Symposium "Plant Protection - Achievements and Prospects", 27-28 October 2020. Chisinau, Republic of Moldova, pp. 111-115.

[15] Dospehov, B. Methodology of field experiments. Moscow, 2012, 352 p. (In Russian).

[16] Adamovics A., Platace R., Gulbe I., Ivanovs S. The content of carbon and hydrogen in grass biomass and its influence on heating value. Engineering for Rural Development, 17, 2018, pp. $1277-1281$

[17] Ivanovs S., Adamovics A., Rucins A. Investigation of the technological spring harvesting variants of the industrial hemp stalk mass. Agronomy Research. Vol. 13 91), 2015, pp. 53-60

[18] Gmurman, V.E., Probability theory and mathematical statistics. Moscow, 2016, 479 p.

[19] Spall J. C. Factorial Design for Efficient Experimentation: Generating Informative Data for System Identification. IEEE Control Systems Magazine, 30 (5), 2010, pp. 38-53. 